\title{
Evaluasi Kinerja PLTS 1000 Wp di Itenas Bandung
}

\section{FERY HIDAYAT, DANI RUSIRAWAN, IQBAL RACHMADI FAJAR TANJUNG}

\author{
Institut Teknologi Nasional Bandung \\ Email: fery@itenas.ac.id
}

\author{
Received 26 November 2018 | Revised 20 Desember 2018 | Accepted 9 Januari 2019
}

\begin{abstract}
ABSTRAK
Pembangkit Listrik Tenaga Surya (PLTS) merupakan salah satu sistem pembangkit non-konvensional yang dapat menggantikan peran pembangkit listrik konvensional. Saat ini Institut Teknologi Nasional Bandung (Itenas) sedang mengembangkan instalasi PLTS 1000 Wp jenis grid connected system, menggunakan modul fotovoltaik (FV) tipe monokristalin. Dalam artikel ini, hasil evaluasi berbagai parameter utama modul FV akan dipaparkan dalam rangka mendapatkan kinerja dari PLTS. Pengukuran parameter utama modul FV dilakukan dengan menggunakan mikrokontroler Arduino Mega 1.8.2 meliputi radiasi matahari $(G)$ dan temperatur lingkungan (Ta), sebagai parameter masukan serta tegangan (V), arus (I) dan temperatur sel/modul FV (TC), sebagai parameter keluaran. Pengukuran parameter utama bertujuan untuk memperoleh daya $(P)$, efisiensi $(\eta)$ serta energi kumulatif $\left(E_{k}\right)$ dari PLTS terpasang. Dari hasil pengujian selama 6 hari, diperoleh daya, efisiensi, dan produksi energi kumulatif rata-rata harian PLTS terpasang adalah 535,99 W/hari, 14,29 \% dan 2,64 kWh.
\end{abstract}

Kata kunci: fotovoltaik, monokristalin, daya dan efisiensi rata-rata harian

\begin{abstract}
The solar power plant (SPP) is one of non convensional power plant, which can be used to substitute the conventional power plant. Presently, Institut Teknologi Nasional (Itenas) has been developed a 1000 Wp grid-connected SPP, using monocrystalline photovoltaic (PV) modules. In this paper, evaluation results of the PV modules parameters will be elaborated to figure out the PV modules characteristics, as a basic to evaluate the SPP performance. The measuring of PV modules have been done using arduino mega 1.8.2 microcontroller. The input parameters of the PV modules are solar radiation (G) and ambient temperature (Ta), meanwhile the output parameters are voltage (V), current (I) and cell/module temperature $(T c)$. All these parameters are used to estimate the power $(P)$, efficiency ( $\eta$ ) and cumulative energy (E). Based on measurements and evaluation during 6 days, it is found that the average of the power and efficiency of the SPP were $535,99 \mathrm{~W} /$ day and $14,29 \%$, respectively, and average yield of energy (daily) was 2,64 kWh.
\end{abstract}

Keywords: photovoltaic, monocrystalline, daily power and efficiency average 


\section{PENDAHULUAN}

Kebutuhan energi listrik untuk kehidupan sehari-hari semakin meningkat seiring dengan berkurangnya cadangan sumber energi fosil. Kondisi ini mendorong usaha untuk mengembangkan energi baru dan terbarukan (EBT). Indonesia yang terletak pada $6^{\circ} \mathrm{LU}$ dan $144^{\circ}$ BT merupakan negara yang memiliki iklim tropis dengan intensitas iradiasi matahari ratarata sebesar $4,5-4,8 \mathrm{kWh} / \mathrm{m}^{2} /$ hari (Stevanus, 2010) dengan lama waktu penyinaran matahari efektif 5 jam/hari (Yuliarto, 2017). Kondisi ini merupakan potensi besar untuk mengembangkan Pembangkit Listrik Tenaga Surya (PLTS) dengan memanfaatkan modul fotovoltaik (FV), yang dapat mengubah secara langsung iradiasi matahari menjadi energi listrik. Pengukuran klimatologi oleh BMKG Stasiun Geofisika Klas 1 Bandung (BMKG, 2016) menyatakan untuk kota Bandung dengan koordinat lintang 06" 53' 00,92750"S, Bujur 107" 35' $50,52075^{\prime \prime}$, DPL 791,679, radiasi matahari rata-rata terukur untuk bulan Januari - September 2016 sebesar $238,67 \mathrm{~W} / \mathrm{m}^{2}$.

Sejak Januari 2018, di Institut Teknologi Nasional Bandung (Itenas) telah dibangun instalasi PLTS kapasitas $1000 \mathrm{Wp}$ (Watt peak) jenis grid-connected system (sistem PLTS yang terhubung dengan jaringan listrik umum). Komponen utama dari PLTS ini adalah modul FV dan inverter. Instalasi PLTS direncanakan akan digunakan untuk penerangan di Gedung 1, lantai 4 Itenas, khususnya di koridor lantai 4. Dengan memperhatikan jumlah lampu yang ada di koridor (11 lampu dengan daya total $252 \mathrm{~W}$ ) serta cuaca yang tidak sesuai dengan kondisi STC, maka dipilih PLTS dengan kapasitas 1000 Wp. Instalasi ini selain akan digunakan sebagai sarana penelitian, juga akan digunakan sebagai sarana edukasi bagi pelajar, mahasiswa dan umum.

Parameter utama modul FV yang mempengaruhi daya keluaran modul FV antara lain radiasi matahari $(G)$, temperatur lingkungan ( $T a)$, dan temperatur sel/modul FV ( $T c$ ). Daya keluaran modul FV sangat dipengaruhi radiasi datang matahari dan temperatur sel, yang secara langsung dipengaruhi oleh temperatur lingkungan (Rusirawan \& Farkas, 2011a).

Dari berbagai karakteristik umum tentang modul FV terlihat bahwa pada temperatur tinggi dan radiasi yang rendah cenderung akan mengurangi kemampuan modul FV dalam menghasilkan daya. Selain itu, peningkatan temperatur modul FV untuk radiasi yang konstan akan menurunkan daya modul FV. Fenomena ini menunjukkkan bahwa daya modul FV dipengaruhi oleh temperatur ambient (lingkungan) (Rusirawan \& Farkas, 2011b).

Sementara itu, kinerja dari modul FV yang direpresentasikan melalui efisiensi, untuk modul FV jenis monokristalin efisiensinya berkisar diantara antara 14-20\% (Osanyinpeju et al., 2018).

Dalam artikel ini nilai hasil pengukuran berbagai parameter utama modul FV akan dipaparkan, sebagai dasar untuk mengevaluasi kinerja dari PLTS 1000 Wp.

\section{METODOLOGI PENELITIAN}

\subsection{Lokasi dan Orientasi Instalasi PLTS 1000 WP}

Penentuan lokasi dan orientasi instalasi PLTS sangat menentukan, agar dapat menghasilkan kinerja yang optimal, efisien dan juga handal. Pemasangan instalasi PLTS harus memperhatikan letak geografi serta sudut kemiringan modul FV terhadap permukaan datar (surface orientation). Jacobson dan Jadhav pada hasil penelitiannya menuliskan bahwa parameter kritis dalam pemasangan modul FV dengan kemiringan tetap adalah tilt-angle, 
karena keluaran modul FV akan meningkat dengan meningkatnya iradiasi matahari secara langsung ke permukaan sel FV (Jacobson \& Jadhav, 2018).

Lokasi dan orientasi instalasi PLTS 1000 Wp di Itenas Bandung diperlihatkan pada Tabel 1. (Perdana, 2017).

Tabel 1. Letak Geografis dan Orientasi Modul FV - PLTS 1000 WP di Itenas

\begin{tabular}{|l|l|l|l|l|}
\hline Lokasi & \multicolumn{4}{l|}{ Bandung } \\
\hline Negara, Kawasan & \multicolumn{4}{l|}{ Indonesia, Asia } \\
\hline & \multicolumn{1}{|l|}{ Desimal } & \multicolumn{1}{l|}{ Derajat } & \multicolumn{1}{l|}{ Menit } & \\
\hline Latitude & $-6,92(')$ & -6 & 55 & + = Utara, - = Belahan Selatan \\
\hline Longitude & 107,60 & 107 & 36 & + = Timur, - = Barat Greenwich \\
\hline Altitude & 698 & M di atas permukaan laut \\
\hline Tilt angle & $12^{\circ}$ & Azimut & (Utara) \\
\hline
\end{tabular}

\subsection{Instalasi FV}

Jenis instalasi PLTS di Itenas adalah Grid Connected System dan menggunakan teknologi modul monokristalin silikon (monocrystalline silicon) tipe JAM 6 60-265 Wp, yang spesifikasinya diperlihatkan pada Tabel 2.

Tabel 2. Spesifikasi Monocrystalline Silicon Module Tipe JAM 6 60-265 WP

\begin{tabular}{|c|c|}
\hline \multicolumn{2}{|c|}{ Spesifikasi Monocrystalline Silicon Module } \\
\hline Tipe & JAM 6 60-265 WP \\
\hline \multicolumn{2}{|l|}{ Parameter Kelistrikan } \\
\hline Reted Maximum Power at STC $(W)$ & 265 \\
\hline Open Circuit Voltage (Voc/V) & 38.26 \\
\hline Maximum Power Voltage (Vmp/V) & 31.11 \\
\hline Short Circuit Current (IsC/A) & 9.00 \\
\hline Maximum Power Current (Imp/A) & 8.52 \\
\hline Modul Efficiency (\%) & 16.21 \\
\hline \multicolumn{2}{|l|}{ Kondisi Operasi } \\
\hline Max. system voltage & DC $1000 \mathrm{~V}$ (IEC) \\
\hline Operating temperature & $-40^{\circ} \mathrm{C}-+85^{\circ} \mathrm{C}$ \\
\hline $\begin{array}{l}\text { NOCT (Nominal Operating Cell } \\
\text { Temperature) }\end{array}$ & $45 \pm 2^{\circ} \mathrm{C}$ \\
\hline \multicolumn{2}{|l|}{ NOCT } \\
\hline Max Power (Pmax) (W) & 193,98 \\
\hline Open Circuit Voltage (Voc) (V) & 35.30 \\
\hline Open Circuit Voltage $(\mathrm{Vmp})(\mathrm{V})$ & 28.52 \\
\hline Short Circuit Current (IsC) (A) & 7.13 \\
\hline Max Power Current (Imp) (A) & 6.79 \\
\hline Kondisi & $\begin{array}{l}\text { Parameter pada kondisi NOCT: Iradiasi } 800 \mathrm{~W} / \mathrm{m}^{2} \text {, AM } \\
1.5 \text {, Temperatur Lingkungan } 20^{\circ} \mathrm{C} \text {, kecepatan angin } 1 \\
\mathrm{~m} / \mathrm{s}\end{array}$ \\
\hline
\end{tabular}

PLTS ini menggunakan 4 buah modul FV yang disusun secara seri dengan kapasitas daya terpasang maksimum $1000 \mathrm{Wp}$. Gambar 1 memperlihatkan skema grid connected system secara umum (Rusirawan, 2015) sedangkan Gambar 2 memperlihatkan instalasi PLTS di Itenas. 


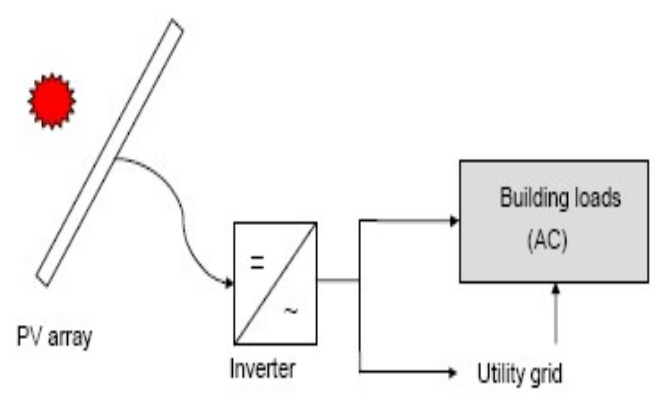

Gambar 1. Grid Connected System

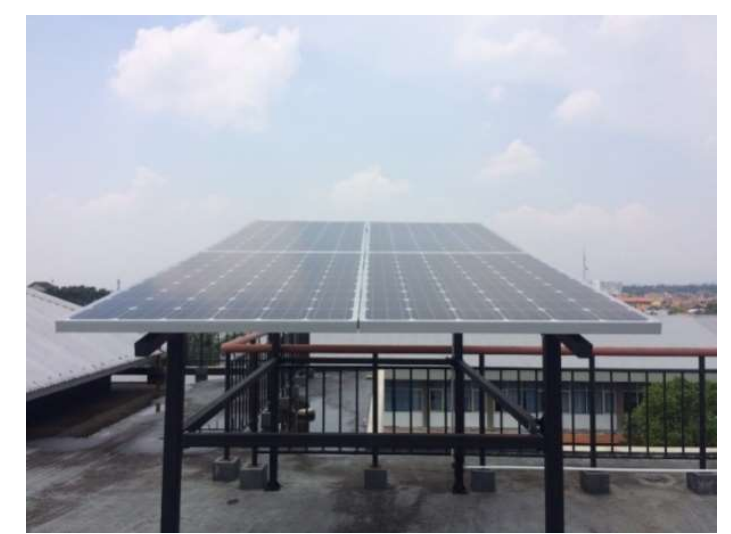

Gambar 2. Instalasi FV PLTS Institut Teknologi Nasional, Bandung

\subsection{Pengujian Kinerja PLTS 1000 WP}

Penelitian dilakukan untuk melihat kinerja PLTS $1 \mathrm{kWp}$ dengan mengukur parameterparameter utama kinerja modul FV yaitu iradiasi matahari $(G)$, temperatur Lingkungan $(T a)$, temperatur sel modul FV $(T C)$, arus keluaran dari modul FV $(I)$ dan tegangan keluaran dari modul FV $(V$. Perancangan dan realisasi alat tambahan untuk pengujian telah dilakukan untuk mendapatkan berbagai parameter utama modul FV.

Pengukuran parameter utama modul FV yang terpasang di instalasi PLTS Itenas Bandung dilakukan selama enam hari dari tanggal 15 Juli 2017 sampai tanggal 20 Juli 2017. Pengukuran dilakukan dari jam 08:00 - 15:00 WIB (7 jam operasi) dengan mempertimbangkan bahwa lama waktu penyinaran matahari efektif (peak sun hours) untuk wilayah Indonesia adalah 5 jam/hari (Yuliarto, 2017). Hasil dari kegiatan pengukuran parameter utama modul FV tersebut kemudian digunakan untuk menghitung kinerja instalasi PLTS dan produksi energi (kumulatif) instalasi PLTS.

Analisis terhadap parameter utama modul FV selama 6 hari pengukuran, direpresentasikan melalui metodologi penelitian dalam bentuk diagram alir seperti diperlihatkan pada Gambar 3. 


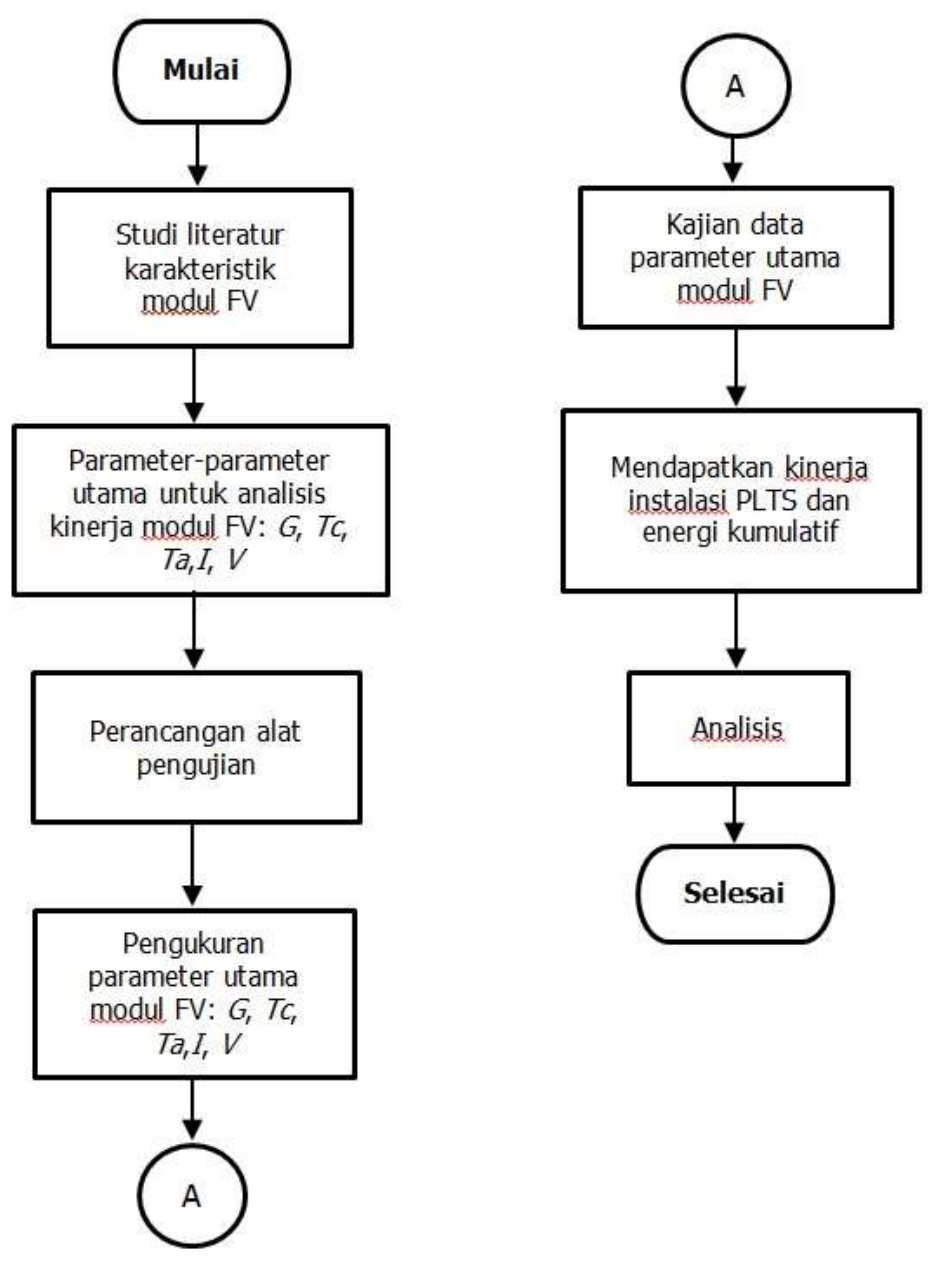

\section{Gambar 3. Diagram Alir Pengujian Kinerja Instalasi FV PLTS Institut Teknologi Nasional}

Pengambilan data berbagai parameter seperti iradiasi matahari, $G\left(\mathrm{~W} / \mathrm{m}^{2}\right)$, temperatur sel modul FV, $T C\left({ }^{\circ} \mathrm{C}\right)$, tegangan keluaran modul $\mathrm{FV}, V$ (Volt), dan arus keluaran modul $\mathrm{FV}, I$ (Ampere) diukur dengan menggunakan mikrokontroler Arduino 1.8.2. Pengukuran data parameter utama modul FV dilakukan setiap interval waktu 10 detik. Skema rangkaian alat pengukuran diperlihatkan pada Gambar 4.

Untuk mengatasi perbedaan tegangan modul FV (maksimum 124,44 DCV) dengan tegangan yang bisa diterima modul Arduino Mega (5 DCV), maka dibuat rangkaian hambatan yang diperlihatkan pada Gambar 4 (dicirikan oleh batas sistem).

Arus $(I)$ dan tegangan keluaran $(V$ modul FV disesuaikan terlebih dahulu dengan arus dan tegangan mikrokontroler melalui rangkaian hambatan $(R)$, untuk selanjutnya diteruskan ke mikrokontroler Arduino melalui pin A5. Hasil pengukuran $I$ dan $V$ akan dibaca oleh serial monitor pada perangkat lunak Arduino 


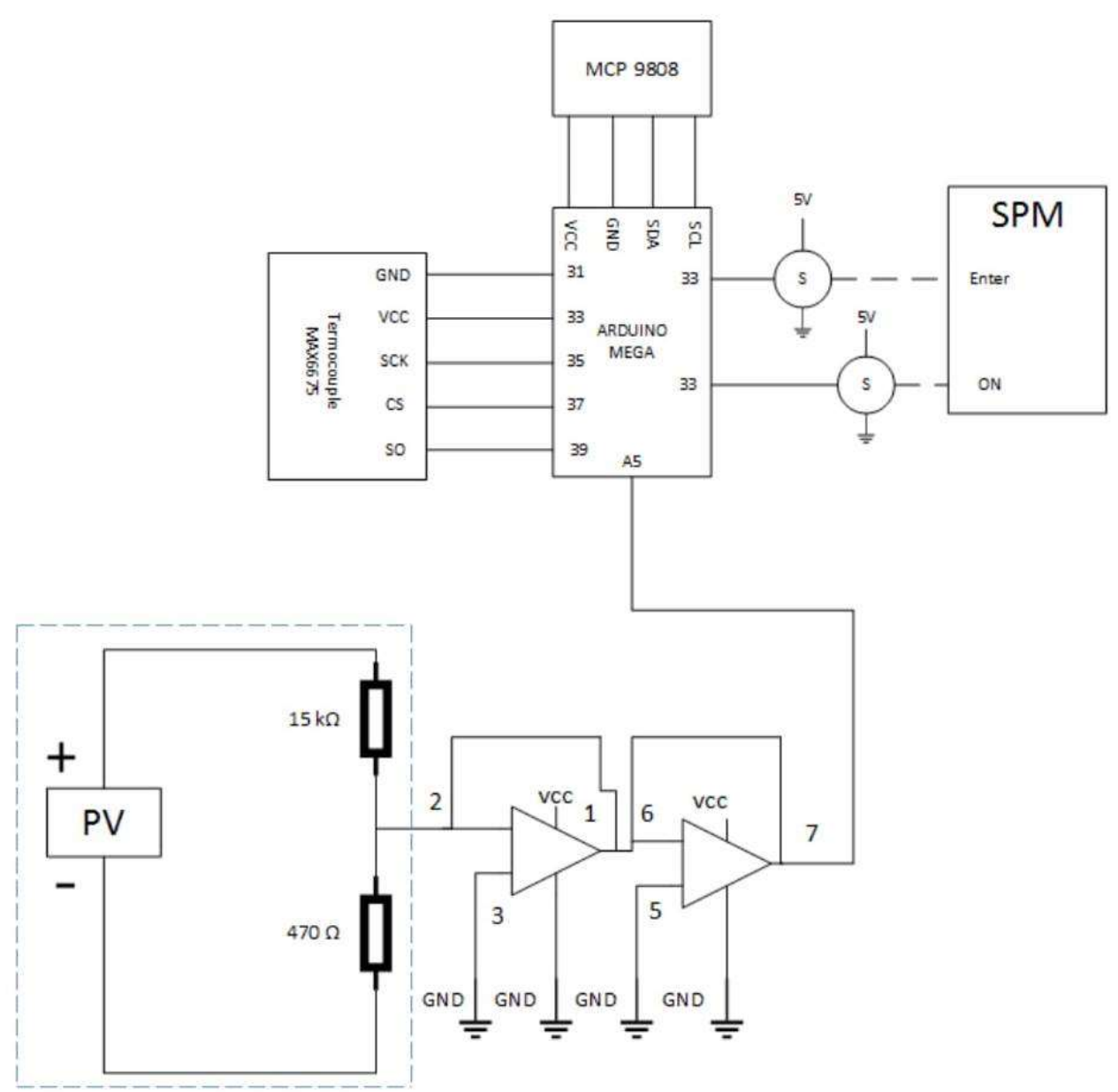

Gambar 4. Skema Rangkaian Alat Pengukuran Parameter Utama FV

Temperatur sel modul FV (TC) diukur dengan menggunakan termokopel MAX 6675 dan temperatur lingkungan ( $T a$ ) diukur dengan sensor temperatur Adafruit 9808. Termokopel MAX 6675 dan sensor temperatur Adafruit 9808 memiliki karakteristik sinyal keluaran digital, maka hasil pengukuran temperatur sel modul FV (TC) dapat langsung ditampilkan pada monitor perangkat lunak Arduino.

Pengukuran iradiasi Matahari (G) menggunakan Solar Power Meter tipe SPM-1116SD. Pengaturan waktu pengukuran terhadap iradiasi Matahari dilakukan dengan menggunakan mekanisme motor servo yang akan mengoperasikan waktu operasi Solar Power Meter secara otomatis disesuaikan dengan waktu pengambilan data pengukuran parameter utama modul FV lainnya. Rangkaian alat dan instalasi alat ukur parameter modul FV dapat dilihat pada Gambar 5. 

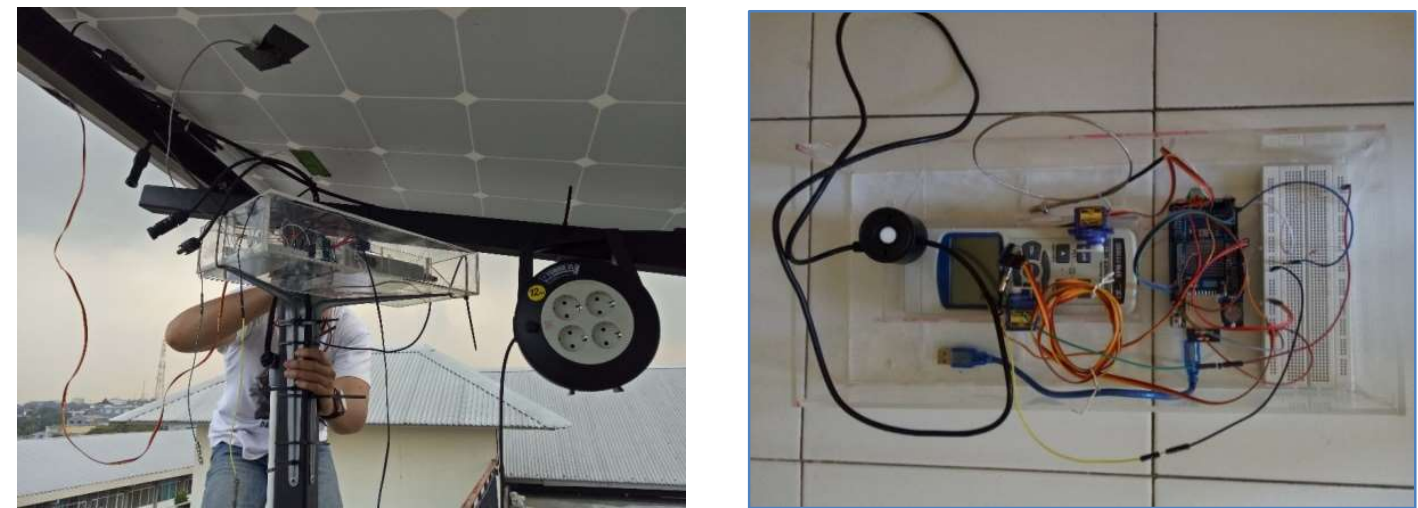

Gambar 5. Rangkaian Alat dan Instalasi Alat Ukur Parameter Utama Instalasi FV

Data hasil pengukuran parameter utama modul FV selanjutnya akan digunakan untuk menghitung daya keluaran modul FV $(P)$ dalam satuan Watt, dan efisiensi daya modul $\mathrm{FV}(\eta)$. Daya keluaran modul FV dihitung dengan menggunakan persamaan berikut ini:

$$
P=V x I
$$

$P=$ Daya Keluaran instalasi FV per jam (Watt)

$V=$ Tegangan Keluaran instalasi FV (Volt)

$I=$ Arus Keluaran instalasi FV (Ampere)

Efisiensi keseluruhan modul FV dihitung dengan menggunakan persamaan:

$$
\eta=\frac{V x I}{G x A}
$$

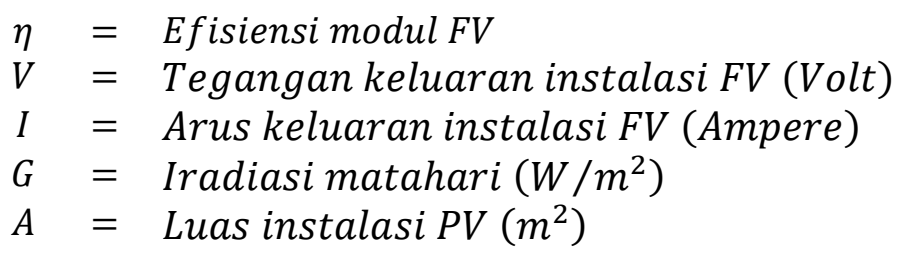

Parameter Fill Factor (FF) diukur dengan membandingkan nilai daya keluaran instalasi modul FV $(P)$ hasil pengukuran terhadap hasil perkalian open circuit Voltage (Voc) dan short circuit Current (IsC) modul FV pada instalasi PLTS Itenas. Parameter FF dihitung dengan persamaan:

$$
F F=\frac{V \times I}{V_{O C} \times I_{S C}}
$$

Perhitungan Energi kumulatif modul FV $\left(E_{k}\right)$ dalam kWh diperlukan untuk mengetahui potensi produksi energi modul FV selama tujuh jam operasi, selama enam hari pengambilan data. 


\section{ANALISIS}

Hasil pengukuran modul FV memperlihatkan bahwa besarnya arus keluaran (I) sangat dipengaruhi oleh iradiasi matahari $(G)$. Dari grafik terlihat bahwa arus keluaran (I) semakin tinggi dengan meningkatnya iradiasi matahari $(G)$. Hasil pengukuran tanggal 16 Juli 2017 memperlihatkan arus keluaran $(I)$ tertinggi adalah 8,50 A pada iradiasi matahari $(G) \quad 1000,45$ $\mathrm{W} / \mathrm{m}^{2}$.

Penurunan iradiasi Matahari ( $G$ ) secara tiba-tiba pada tanggal 15 Juli 2017, jam 11 (awalnya $925,28 \mathrm{~W} / \mathrm{m}^{2}$ kemudian turun menjadi $762,4 \mathrm{~W} / \mathrm{m}^{2}$ ) terjadi karena pengaruh cuaca. Kondisi ini menyebabkan penurunan arus (I) dari 7,94 A menjadi 6,66 A. Grafik hasil pengukuran arus keluaran ( $I$ ) terhadap iradiasi Matahari $(G)$ untuk pengukuran tanggal 15 - 20 Juli 2017 diperlihatkan pada Gambar 6 dan Gambar 7.

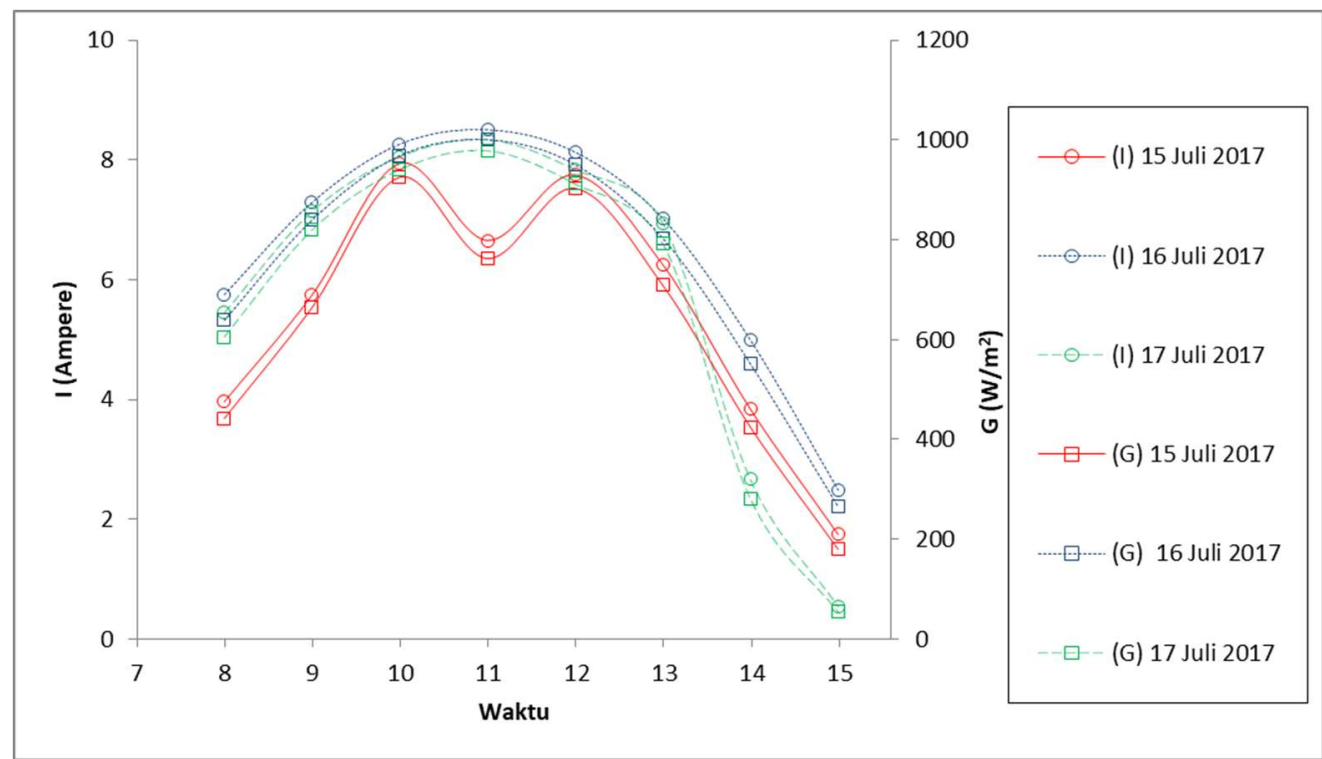

Gambar 6. Hasil Pengukuran I Vs GTanggal 15 - 17 Juli 2017

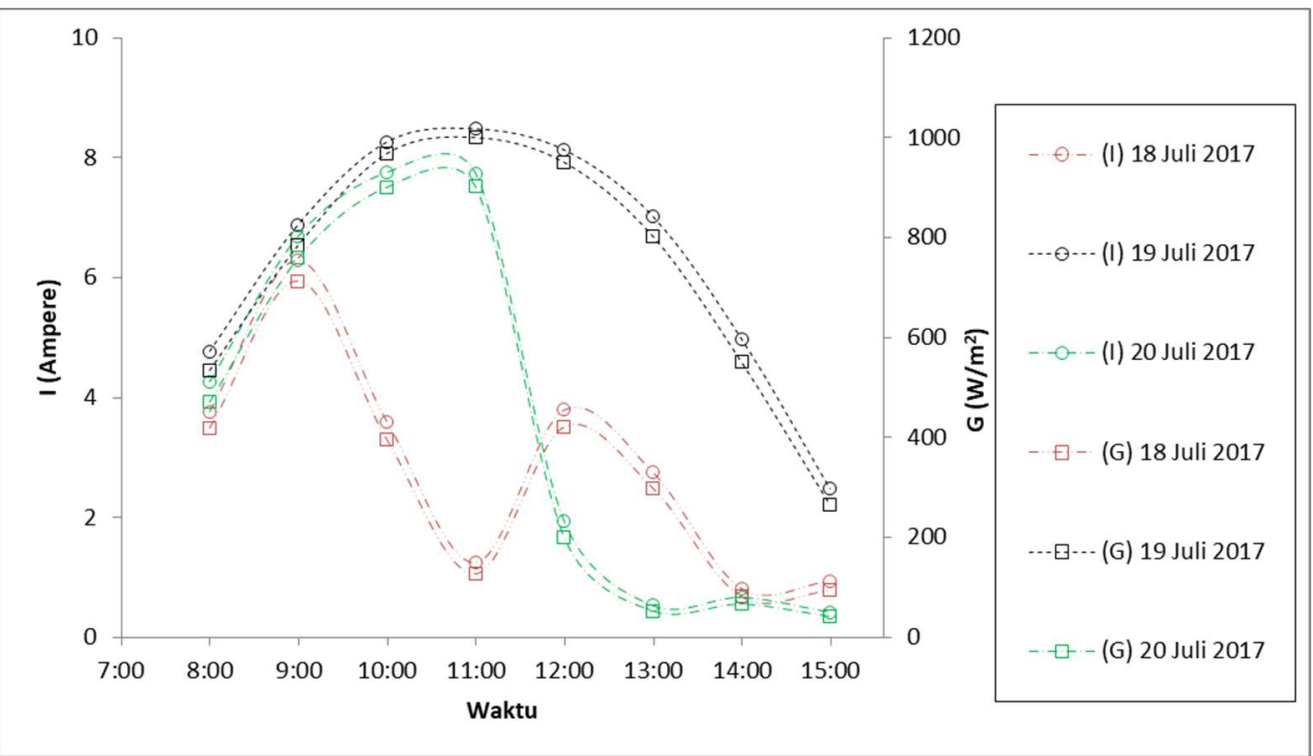

Gambar 7. Hasil Pengukuran I Vs G Tanggal 18 - 20 Juli 2017 
Tegangan keluaran modul FV $(V$ dari hasil pengukuran tidak mengalami pengaruh yang signifikan terhadap perubahan iradiasi Matahari $(G)$, untuk pengukuran tanggal $15-17$ Juli 2018. Namun pada pengukuran tanggal 18 Juli 2018 tidak terjadi perubahan tegangan keluaran ( $V$. Nilai $V$ pada tanggal 18 Juli konstan $101.51 \mathrm{~V}$ selama pengujian, walau nilai iradiasi Matahari $(G$ ) berfluktuasi. Nilai $V$ yang konstan terjadi akibat alat ukur mengalami gangguan teknis sehingga terjadi kesalahan dalam pembacaan $V$. Grafik hasil pengukuran tegangan keluaran $(V$ terhadap iradiasi Matahari $(G)$ untuk pengukuran tanggal $15-20$ Juli 2017 dapat dilihat pada Gambar 8 dan Gambar 9.

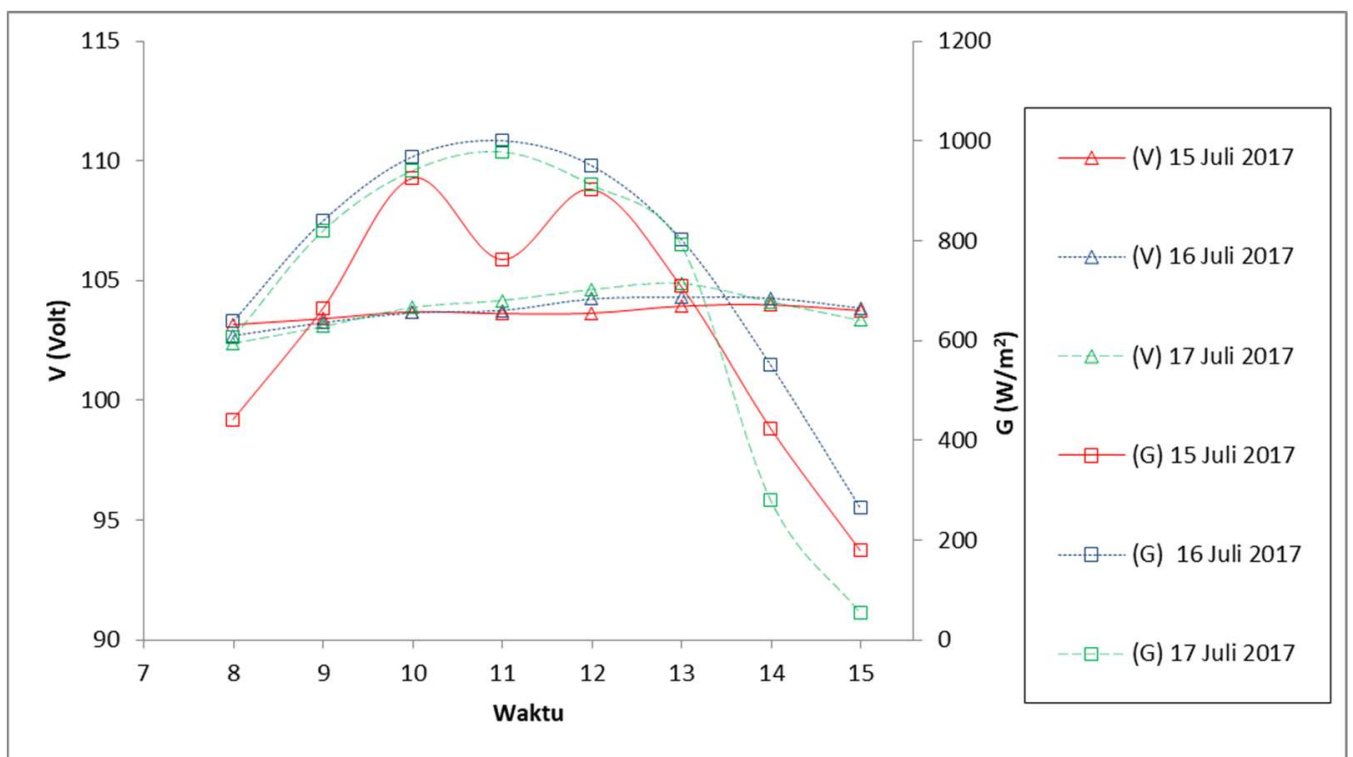

Gambar 8. Hasil Pengukuran V Vs G Tanggal 15 - 17 Juli 2017

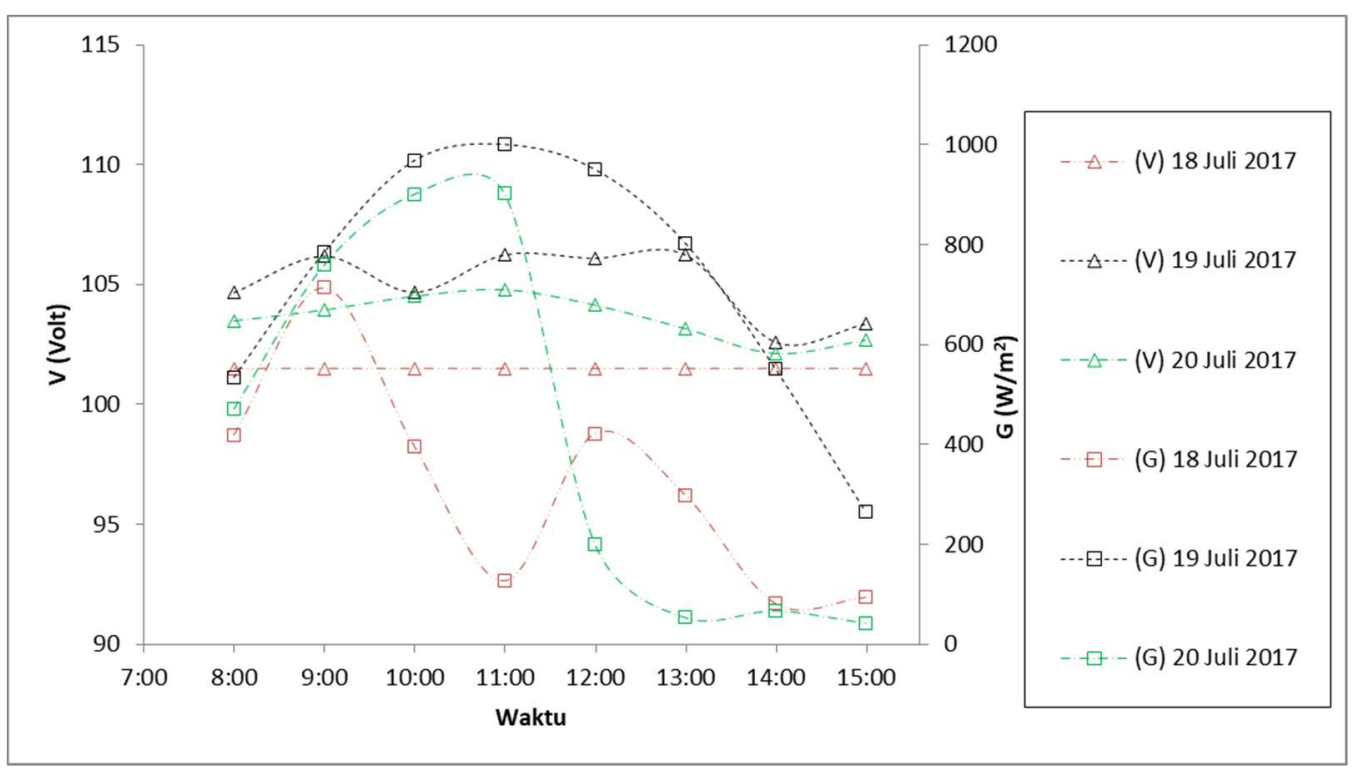

Gambar 9. Hasil Pengukuran V Vs G Tanggal 18 - 20 Juli 2017

Perhitungan daya keluaran modul FV $(P)$ diperlihatkan pada Gambar 10. Gambar ini memperlihatkan fluktuasi daya, khususnya pada tanggal 15, 18, dan 20 Juli 2017. Kondisi ini terjadi karena terdapat korelasi antara nilai $I$ dan $G$. 


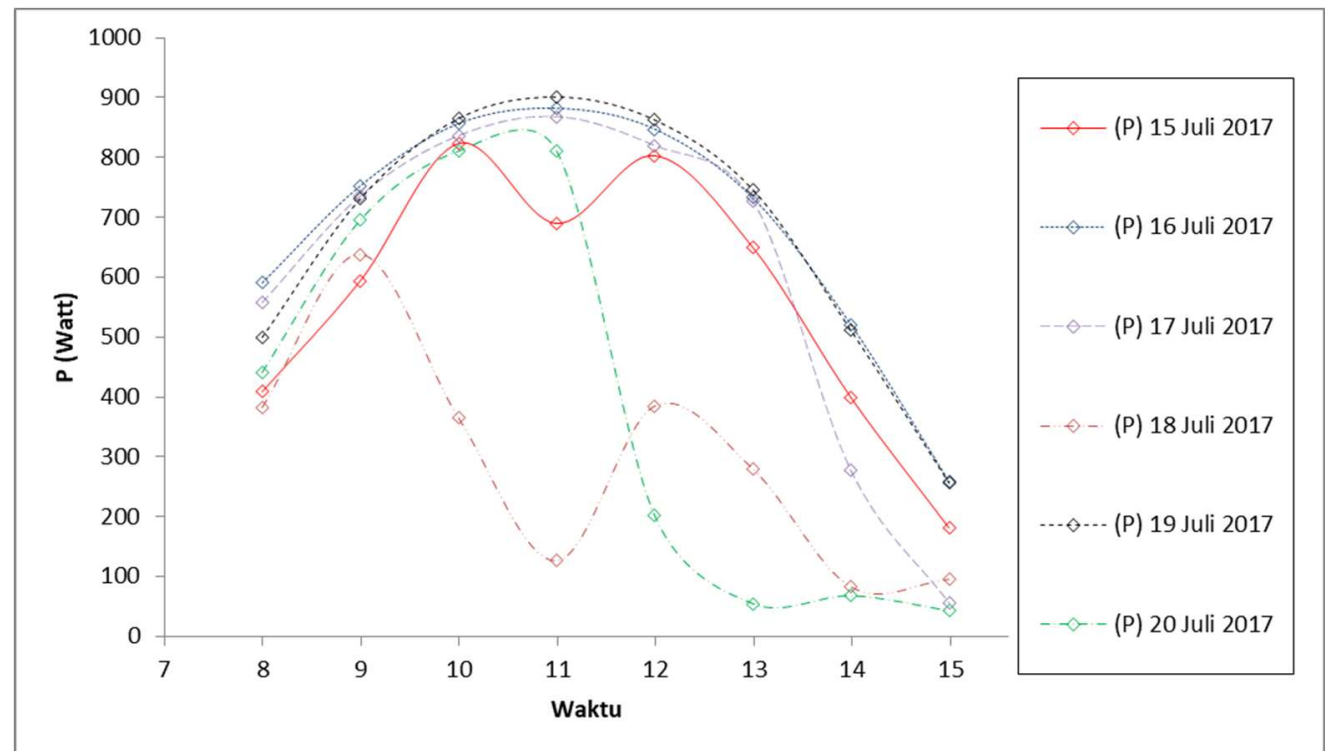

Gambar 10. Hasil Perhitungan PVs G Tanggal 15 - 20 Juli 2017

Sementara itu, hasil perhitungan efisiensi dari modul FV diperlihatkan pada gambar 11-12 yang memperlihatkan nilai efisiensi modul FV dipengaruhi oleh temperatur sel FV. Dari Gambar 11 dan 12 terlihat bahwa $\eta$ modul FV cenderung normal pada interval temperatur operasi ( $T C$ ) $25^{\circ} \mathrm{C}-40^{\circ} \mathrm{C}$, sementara $\eta$ akan cenderung turun apabila $T c$ terus meningkat Pada saat $T C$ turun terlihat nilai $\eta$ meningkat kembali.

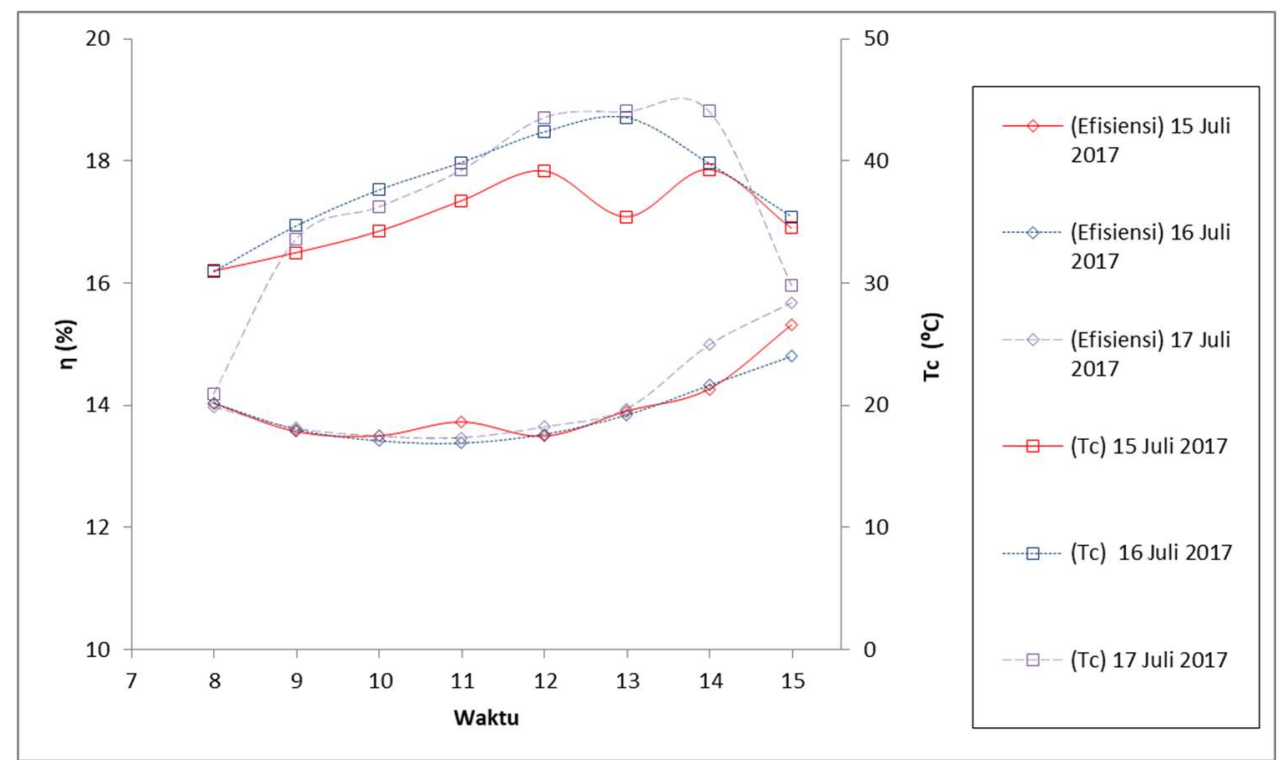

Gambar 11. Hasil Perhitungan ク Vs TcTanggal 15- 17 Juli 2017 


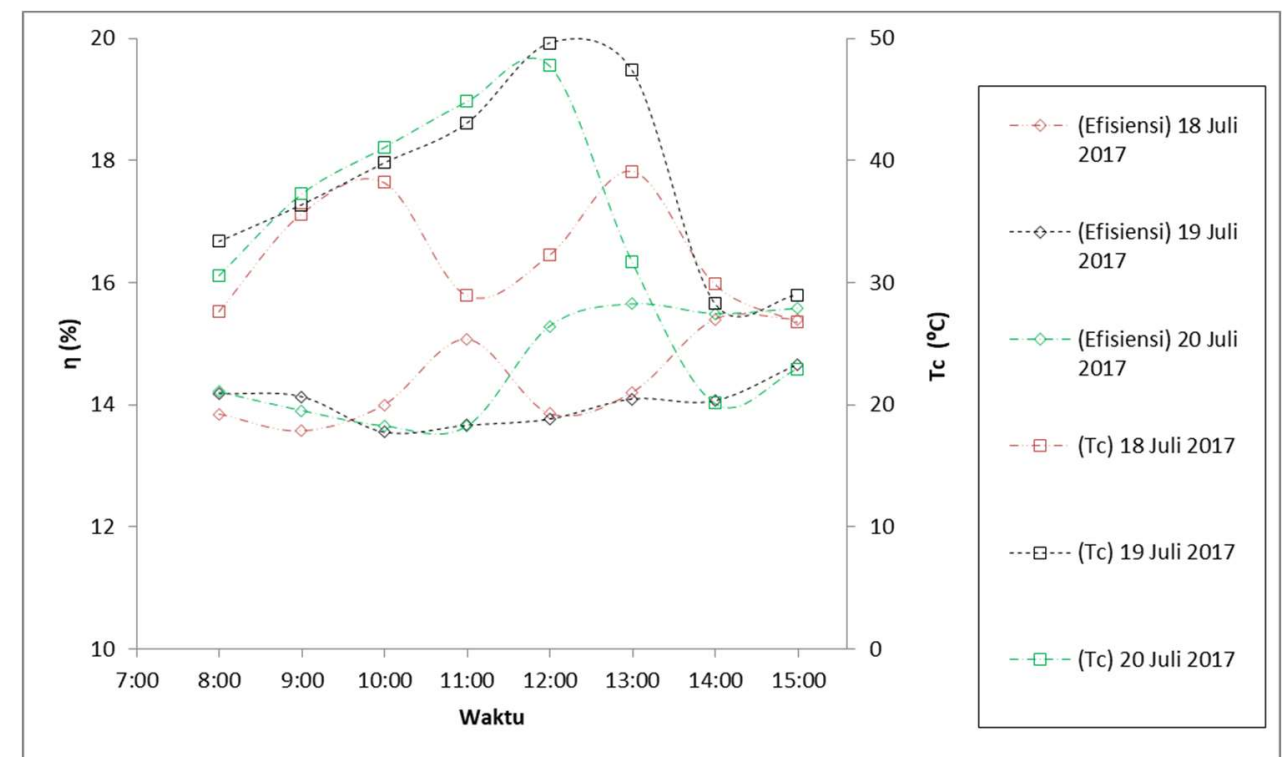

Gambar 12. Hasil Perhitungan n Vs TcTanggal 18- 20 Juli 2017

Gambar 13 memperlihatkan nilai Fill Factor (FF) untuk hasil pengukuran tanggal 15 Juli 2017. Nilai $F F$ tertinggi pada tanggal 15 Juli 2017 adalah 0,6 dan masih di bawah nilai $F F$ maksimum yaitu 0,77 (berdasarkan spesifikasi modul FV).

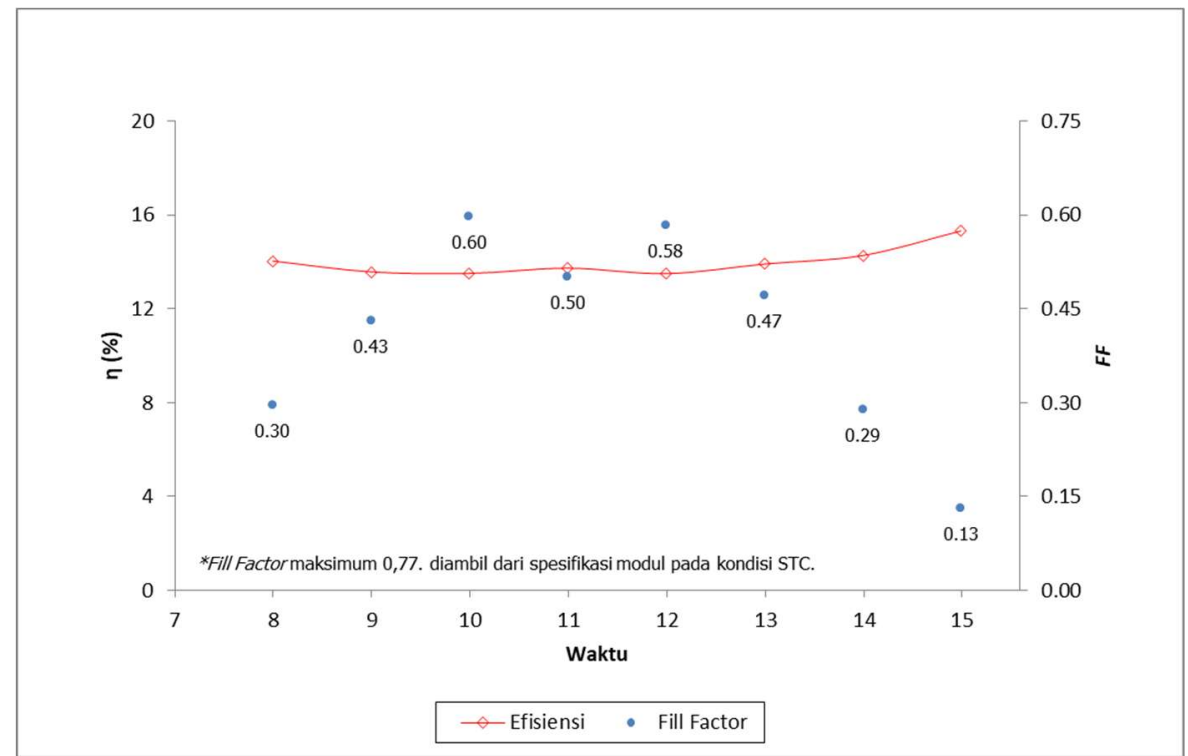

Gambar 13. Grafik $\eta$ Vs FF, Pengukuran Tanggal 15 Juli 2017

Gambar 14 memperlihatkan hasil perhitungan efisiensi rata-rata harian pada tanggal 15-20 Juli 2017. Dari grafik ini terlihat bahwa efisiensi rata-rata harian modul FV terendah terjadi pada tanggal 16 Juli 2017 yaitu 13,87 \%, dan tertinggi terjadi pada tanggal 20 Juli 2017 yaitu $14,68 \%$.

Gambar 15 memperlihatkan produksi energi kumulatif modul FV (kWh) selama 4 hari pengamatan (15 - 18 Juli 2017), yang dihitung selama tujuh jam operasi efektif, jam 08:00 15:00 WIB. Produksi energi kumulatif diluar jam operasi efektif tidak diperhitungkan dengan pertimbangan bahwa Iradiasi Matahari sudah tidak dapat dikonversikan menjadi energi listrik. 


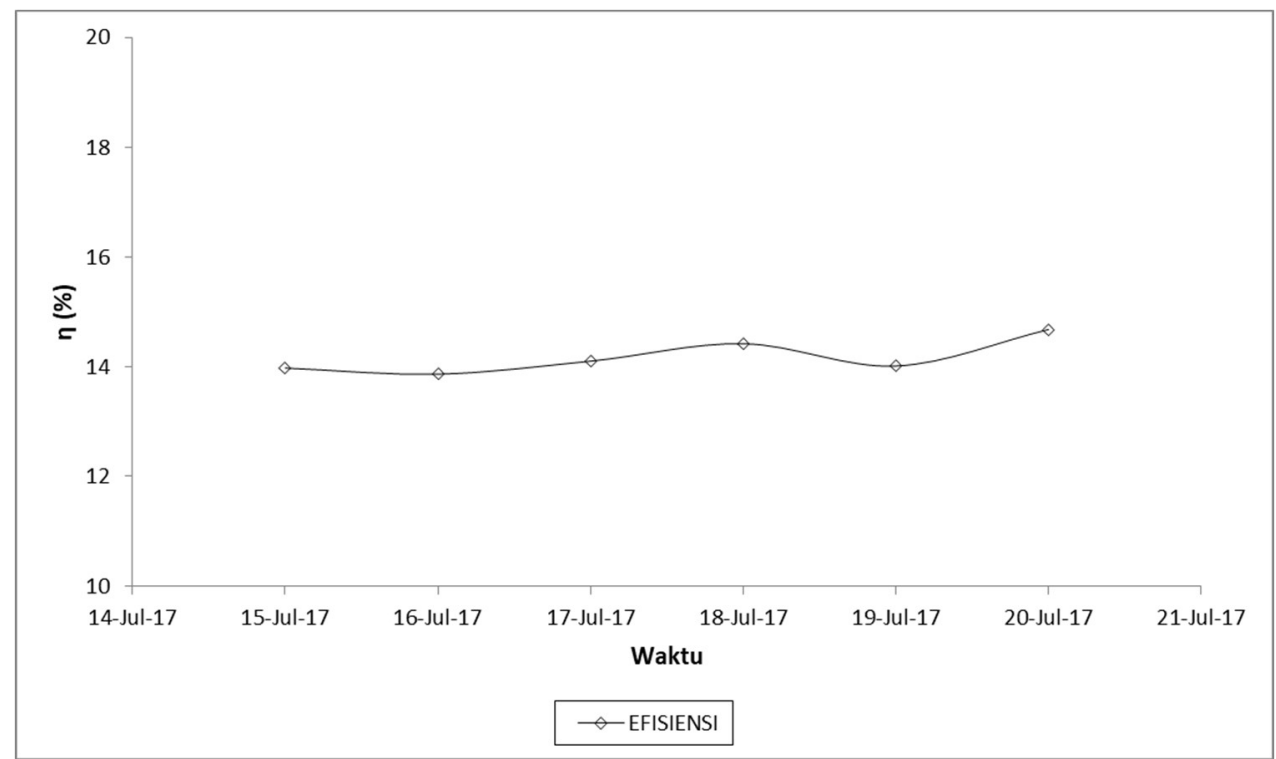

Gambar 14. Grafik n Rata-rata Harian Modul FV

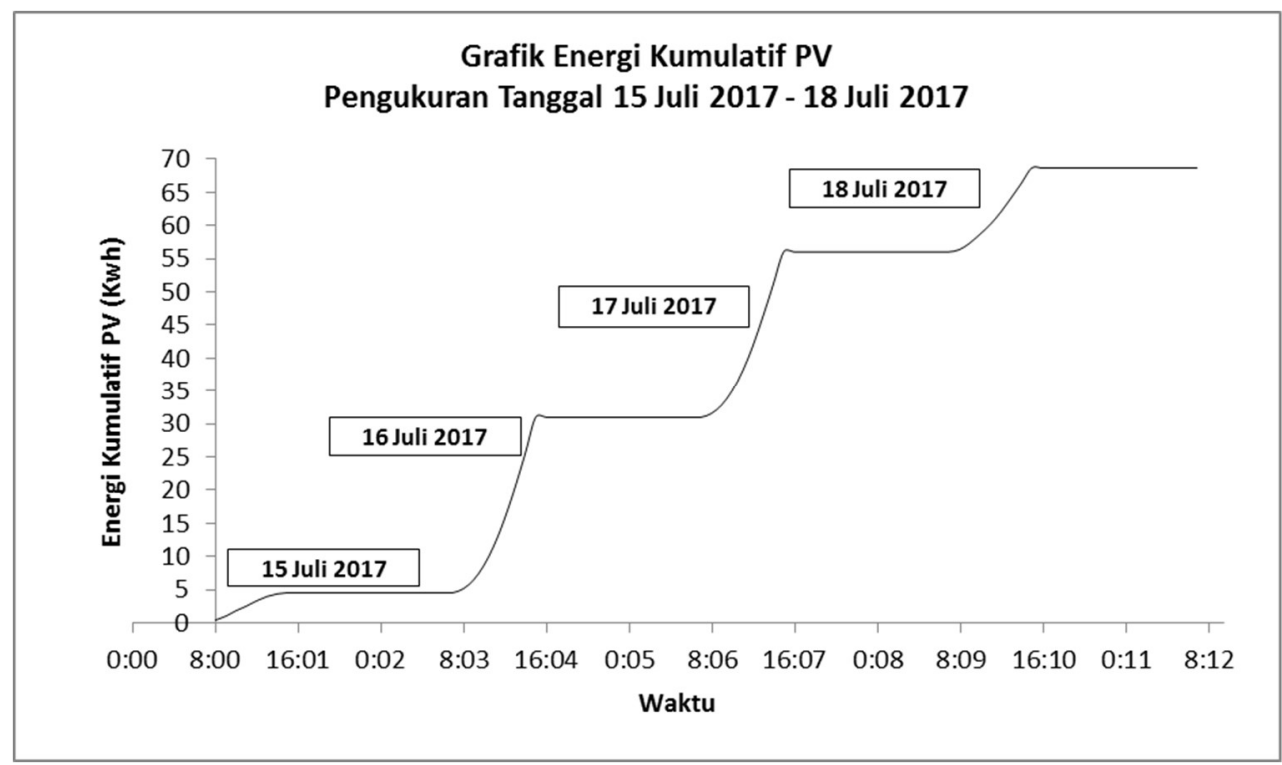

Gambar 15. Grafik Energi Kumulatif Instalasi FV

Hasil pengukuran terhadap performansi kinerja modul FV pada PLTS Itenas diperlihatkan pada Tabel 3.

Tabel 3. Performansi Kinerja Modul FV di PLTS Itenas

\begin{tabular}{|c|c|c|c|c|c|c|c|}
\hline \multirow{2}{*}{ Tanggal } & \multicolumn{7}{|c|}{ PARAMETER KINERJA MODUL FV } \\
\cline { 2 - 8 } & Radiasi & $\begin{array}{c}\text { Temperatur } \\
\text { Sel FV }\end{array}$ & $\begin{array}{c}\text { Temperatur } \\
\text { Lingkungan }\end{array}$ & Tegangan & Arus & Daya & Efisiensi \\
\cline { 2 - 8 } & $\mathbf{( W / \mathbf { m } ^ { 2 } )}$ & $\left({ }^{\mathbf{}} \mathbf{C}\right)$ & $\left({ }^{\circ} \mathbf{C}\right)$ & $(\mathbf{V})$ & $(\mathbf{A})$ & $(\mathbf{W})$ & $(\%)$ \\
\hline 15-Jul-17 & 626.16 & 35.37 & 29.97 & 103.65 & 5.49 & 568.59 & 14.09 \\
\hline 16-Jul-17 & 752.16 & 38.04 & 31.66 & 103.76 & 6.56 & 680.20 & 13.97 \\
\hline 17-Jul-17 & 672.86 & 36.45 & 32.88 & 103.81 & 5.87 & 610.06 & 14.21 \\
\hline 18-Jul-17 & 319.05 & 32.30 & 29.31 & 101.51 & 2.90 & 294.54 & 14.53 \\
\hline 19-Jul-17 & 732.35 & 38.37 & 33.09 & 105.01 & 6.38 & 671.64 & 14.12 \\
\hline 20-Jul-17 & 424.40 & 34.52 & 32.47 & 103.61 & 3.75 & 390.90 & 14.79 \\
\hline Rata-rata total & $\mathbf{5 8 7 . 8 3}$ & $\mathbf{3 5 . 8 4}$ & $\mathbf{3 1 . 5 6}$ & $\mathbf{1 0 3 . 5 6}$ & $\mathbf{5 . 1 6}$ & $\mathbf{5 3 5 . 9 9}$ & $\mathbf{1 4 . 2 9}$ \\
\hline
\end{tabular}




\section{KESIMPULAN}

Pengukuran terhadap parameter utama modul FV pada instalasi PLTS di Institut Teknologi Nasional Bandung sudah dilakukan dan hubungan berbagai parameter seperti $G, V, I$, Tcsudah direpresentasikan melalui berbagai kurva/grafik.

Dari hasil pengukuran dapat disimpulkan bahwa iradiasi matahari rata-rata harian tertinggi terjadi pada tanggal 16 Juli 2017 sebesar 752,16 W/m² dengan daya keluaran modul FV mencapai $680,2 \mathrm{~W}$. Daya keluaran modul FV sangat dipengaruhi oleh parameter utama modul FV. Daya rata-rata harian modul FV selama enam hari pengukuran adalah $535 \mathrm{~W} /$ hari.

Daya rata-rata harian modul FV selama enam hari pengukuran sebesar 535,99 W/hari masih di atas kebutuhan daya yang dibutuhkan 11 (sebelas) lampu TD-L, yaitu sebesar $252 \mathrm{~W} /$ hari. Berdasarkan data ini, terlihat bahwa penambahan beban masih sangat dimungkinkan.

Sementara itu, efisiensi tertinggi yang dicapai modul FV selama pengukuran adalah $14,79 \%$, dan efisiensi rata-rata harian selama enam hari pengukuran parameter utama FV adalah 14,29 $\%$. Berdasarkan kedua nilai efisiensi ini dapat disimpulkan bahwa efisiensi modul FV masih di bawah spesifikasi modul FV sebesar 16,21\% (untuk kondisi STC). Efisiensi sebesar 14,29\% sesuai dengan kisaran harga efisiensi untuk suatu modul FV monokristalin yaitu $14 \%$ hingga $20 \%$.

\section{UCAPAN TERIMA KASIH}

Penulis mengucapkan terima kasih kepada Lembaga Penelitian dan Pengabdian Masyarakat (LPPM) Institut Teknologi Nasional Bandung dan Direktorat Jendral Pendidikan Tinggi (DIKTI) atas dukungan finansialnya melalui Hibah Penelitian Unggulan Perguruan Tinggi (PUPT) melalui kontrak nomor: 146/B.05/LPPM-ITENAS/VI/2016.

\section{DAFTAR RUJUKAN}

BMKG, stasiun G. K. 1 B. (2016). Data Klimatologi. Bandung.

Jacobson, M. Z., \& Jadhav, V. (2018). World estimates of PV optimal tilt angles and ratios of sunlight incident upon tilted and tracked PV panels relative to horizontal panels. Solar Energy, 169, 55-66.

Osanyinpeju, K. L., Aderinlewo, A. A., Adetunji, O. R., \& Ajisegiri, E. S. A. (2018). Performance Evaluation of Mono-Crystalline Photovoltaic Panels in Funaab , Alabata , Ogun State , Nigeria Weather Performance. International Journal Of Innovations In Engineering Research And Technology, 5.

Perdana, A. Z. (2017). Karakterisasi PLTS Kapasitas 1000 WP. Itenas: Tugas Akhir Jurusan Teknik Mesin. Bandung.

Rusirawan, D. (2015). Perkembangan Terkini Teknologi Fotovoltaik dan Potensi Pemanfaatannya untuk Memenuhi kebutuhan Energi di Indonesia. Materi Orasi IImiah Dies Natalis Itenas ke-43. Bandung. 
Rusirawan, D., \& Farkas, I. (2011a). MPPT Algorithm Effect on The Performance of a Small Scale Grid Connected PV Array System. International Solar Energy Society Conference. Rusirawan, D., \& Farkas, I. (2011b). Simulation of Electrical Characteristic of Polycrystalline and Amorphous PV Modules. EEA Electrotehnica Electronica Automatica, 59(2),9-15.

Stevanus, W., Elektro, J. T., Teknik, F., \& Diponegoro, U. (2010). Sistem Instalasi PLTS 1000 WP Sitting Ground. UNDIP: Makalah Seminar Kerja Praktek Teknik Elektro. Semarang. Yuliarto, B. (2017). Memanen Energi Matahari. Bandung: ITB. 